\title{
The Non-Property Personal Rights and Obligations of Parents Towards Children
}

\author{
Anilda Shestani \\ Phd Cand., Albania, email: agurakuqi@yahoo.com
}

Abstract:

Parental responsibility is already defined in the Family Code as "the totality of the rights and obligations that aimed to ensure emotional, social and material welfare of the child, taking care, maintaining personal relations with him, and assuring him welfare, education, legal representation and administration of his property". In this paper will be analyzed the parental rights and obligations that exercised about the personality of the child that arise as a result of personal non-property relations. This set of rights and duties is different from the other groups of rights and obligations of parent exactly for the lack of their economic content. Parental rights and obligations are the same regardless of the source of birth of parental relationship, biological or declaration of the will on one side, or regardless of the status of children born from the marriage or outside it, on the other side. The concept of the relationship between parents and children has changed a lot from the past in the time that we live today. In the modern concept, parental authority in exercising the rights and obligations to children is conceived in the interest of minors implying therefore the idea of protection that parents are obligated towards their children. This paper will also show how the non-property personal rights and obligations of parents towards the children are applicable in the practice; what are the main problems that appeared during this process and best recommendations for an efficient exercise of these rights and obligations based on the best interest of the child.

Keywords: Parental responsibility, marriage, family, children, non-property rights and obligations, welfare, education.

\section{Parental responsibility and children}

The Albanian family legislation has paid special importance to the relationship between parents and their children. The concept of parental responsibility is an evolution in the way of conceiving of the parent-child relationship. With special emphasis on "responsibility", the legislator wanted to show the essence of the status of the parents, which in itself constitutes a right to assume obligations and respectfully with them to benefit rights in connection to the natural and legal relationship between them and the child 1 . As well as every legal relationship between parents and children it has essentially its rights and obligations. These rights are closely linked with the figure of parent and child as well.

The totality of all rights and obligations of that are carried at parental responsibility are non-transferable to other persons. Parental rights and obligations are the same regardless of the source of the birth of parental relationship or regardless of the legal status of the child.

\section{The non-property personal rights and obligations of parents towards children}

Considering the economic content or not, from the totality of the rights and obligations involved in parental responsibility, we could mention the parental rights and obligations that are exercised in connection with the child's personality and that arise as a result of personal non-property relations. Personal rights are part of the category of absolute rights. Parents may

\footnotetext{
${ }^{1}$ H.Kotherja,E.Abdiu, K.Gega, Manual in the implementation of Family Code and internal civil legislation regarding minors issues, Save the Children and School of Magistrates, 31. 
request for taking measure against any person who infringes them in the exercise of parental rights. These rights cannot be alienated to legal action between the living persons and cannot even pass through the heritage of others.

Also, as a result of this feature, the personal rights of parents and children not undergo to any terms of prescription ${ }^{1}$.

If we take a look at the provisions of the Family Code in Albania, the Article 220 of this Code sanctions that parental responsibility is exercised jointly by both parents for children born during the marriage or born out of wedlock but recognized by the parents.

This means that the non-property personal rights and obligations of parents towards children should exercised by both parents. So just being a parent if biological or adoptive one, the Albanian law has guaranteed the parental responsibility and this responsibility is equal between both parents.

The non-property personal rights and obligations of parents towards children are grouped as follows:

-Care for children; Upbringing.

- Education and schooling of children.

- The right to maintain personal relations with the child.

- Representation of the child and the protection of his interests.

- The right to consent to adoption of the child.

The Family Code in the Article 3 has defined and sanctioned the right but also the duty at the same time of the parents to care for the upbringing, development, well-being and education of children born from marriage or out of wedlock.

Also, if we refer to Article 215 of the Family Code, good care for children it is one of the legal obligations arising from the legal relationship with non-economic character between parents and their children.

But the Family Code has not precisely defined what is meant by the "upbringing of the child." To understand the legal obligation of parents to children in order to ensure the welfare of the children we should refer to legal doctrine and interpretation of children's rights standards established by the Convention on the Rights of the Child (UN) ${ }^{2}$.

Thus, Article 27 of the Convention of the Rights of the Child, the first paragraph states: "States Parties recognize the right of every child to a standard of living adequate for physical, mental, spiritual, moral or social development of him".

The second paragraph of this article defines the fact that the child's parents or responsible persons for the children, they have the primary responsibility to secure within their capacity or capabilities and professional capacities, all the necessary conditions of living for the child's development. "

This article basically highlights the need and necessity of fulfilling the rights of children with regard to nutrition, clothing and housing ${ }^{3}$. These rights should be fulfilled by the parents of child but also an important actor to be included in this process should be the State itself. But this does not mean that we should limit only in securing of these rights for children.

Upbringing of the child itself means:

- Ensuring the health, physical and psychological development of the child;

- Provision of material welfare.

- Provide emotional and social welfare.

\footnotetext{
1 S.Omari, 2012, Family Law, paragraph I,367.

${ }^{2}$ H.Kotherja,E.Abdiu, K.Gega, Manual in the implementation of Family Code and internal civil legislation regarding minors issues, Save the Children, QSHPLI and School of Magistrates, 35

3 In this article is determined that States parties (that have ratified the Convention, as is the case of Albania), in accordance with national conditions and within their means, shall take appropriate measures to assist the parents but the other persons responsible for child to implement the right to an adequate standard of living and in case of need provide material support and support programs, particularly with regard to nutrition, clothing and housing.
} 
- Safeguarding and supervision of the child.

- Measures should be taken with educational character.

If we refer to Article 54 of the Constitution of Albania, this article specifies that the category of children enjoys special protection by the state regarding the health of their physical development. From this article derives the legitimate and fundamental right of children to have a healthy life. Therefore, their parents based on what is called "parental responsibility" have the obligation to ensure the conditions necessary for children to have a healthy life. Beside the obligation of parents to take care of health, physical and psychological development of children, appear the state which through legislation in the field of health offers a wide range of services in order to ensure a better ongoing of the health of the children.

Provision of material welfare although seems to have economic character and therefore related to incomes, in family law, is projected and involved in the rights and duties of parents with non-economic character.

Parents have a responsibility to provide the best goods to children for living. Material welfare includes all the actions undertaken by the parents in order to provide to children not only all the necessary means for life but also the material goods that serve for a dignified life'.

\section{But what will be considered as "necessary means"?}

The answer to this question has actually evolved from one time to another. It actually continues to constantly evolve by taking into account not only social and economic development of a country, the real possibilities of parents but also based on the requirements of the children. By necessary means are included: expenses for food, clothing, medical care and health services, education and other social demands of child².

Also parents have the right and obligation to be involved in the upbringing and education of the child. Parents must have engagement to transmit to the child certain rules of behavior. In no case is legitimate, based on internal or international laws $^{3}$ the corporal punishment of children as a means of disciplining the child. Education ${ }^{4}$ also is another obligation of parents to the child. If this obligation will not be fulfilled it means that there exist conditions for a misuse of the parental responsibility.

The right to maintain personal relations with the child is sanctioned in Article 215 of the Family Code which states that parents have the right to maintain personal relationships with children. For a much better upbringing, efficient supervision and better education of children is in the best interest of the child to maintain personal relationships with parents.

Also Article 219 of the Family Code provides that parents have an obligation to not stop child have personal relationships with his grandparents, except for cases when there are grave reasons. This article also determines that if there are disputes between the parties is the court which can decide on the manner of regulation of these relationships. For example, judicial practice shows how a grandmother sues the mother of children, that after the dead of the children's father, she refused to children meetings with the grandmother by father side ${ }^{5}$. The aassessments made by the Court, classified the behaviors of the grandmother toward children as grave causes in terms of Article 219 of the Family Code, which oblige the court to intervene in the regulation of these relationships in the interest of minors.

\footnotetext{
1 H.Gashi, A.Aliu.A.Vokshi, 2012, Commentary Family Law in Kosovo, LFK-First Edition, 303.

2 S.Omari, 2012, Family Law,368

${ }^{3}$ See: Article 17 , paragraph 1 of the Convention of the Rights of Children that states: "States Parties shall take all appropriate legislative, administrative, social and educational measures to protect the child from all forms of physical or mental violence, injury or abuse, neglect ore negligent treatment, maltreatment or exploitation, including sexual abuse, while in the care of parent (s), legal guardian (s) or any other person who has the care of the child"

${ }^{4}$ Based on the Law no. 7952 date 21.06.1995(changed) of "Pre- university educational system in Albania" sanctions that the 9-year education is mandatory.

${ }^{5}$ H.Kotherja,E.Abdiu, K.Gega, Manual in the implementation of Family Code and internal civil legislation regarding minors issues, Save the Children, QSHPLI and School of Magistrates, 39.
} 
Based on the definition of parental responsibility, parents have the obligation to legal representation of children in carrying out various legal actions of their parents. Minors up to age 14 in all legal actions are represented by parents; their legal representatives or guardians.

Every legal action by which benefits the minor are performed by their parents or guardians on their behalf. Otherwise the actions committed by minors are null. For several juridical actions are required the consent of the competent court or that of the council of guardianship. For any damage caused, parents and guardians should respond, but also the minor in exceptional cases ${ }^{1}$.

Finally, as a right of parents with non-economic character, the Family Code, in articles 569,570 , has sanctioned the right of biological parents to give consent for adoption for their minor child. To biological parents is also recognized the right to withdraw the consent for the adoption of their child till the moment of taking the decision of adoption by the court.

\section{Conclusions}

Parental responsibility is the totality of the rights and obligations that aimed to ensure emotional, social and material welfare of the child, taking care, maintaining personal relations with him, and assuring him welfare, education, legal representation and administration of his property. Parental rights and obligations are the same regardless of the source of birth of parental relationship, biological or declaration of the will on one side, or regardless of the status of children born from the marriage or outside it, on the other side. Parents should fulfill the non-property personal rights and obligation toward children taking into account the best interest of the child. Parents should exercise properly the rights and obligation with no-economic character towards children. Parents, authorities and courts in their decisions and actions should have as main consideration the highest interest of the child. Interest and welfare of the child shall be a primary consideration.

\section{References}

Commentary of Family Law in Kosovo, LKF- First Edition, H.Gashi, L.Aliu,A.Vokshi, 2012.

Constitution in Albania.

Civil Code in Albania, Law no. 7850 date 29.07.1994, published by the Center of Legal Publishing, 2012.

Family Code in Albania, Law no. 9062 date 8.5.2003, published by the Center of Legal Publishing, 2012.

Family Law, S.Omari,2012

Manual Manual in the implementation of Family Code and internal civil legislation regarding minors issues, H.Kotherja, E.Abdiu, K.Gega, Save the Children; QSHPLI and School of Magistrates.

International Convention of the Rights od Children, 1989.

The status of minors, M.Tutulani, 2008.

Law no.7952 date 21.06.1995 (changed) of "Pre-university educational system in Albania"

${ }^{1}$ M.Tutulani, 2008, The status of minors, 44. 